\title{
Spatial analysis of groundwater level monitoring network in the Danube-Tisza Interfluve using semivariograms
}

\author{
BALÁzs KOHÁN ${ }^{1,2}$ and József SZALAI ${ }^{3}$
}

\begin{abstract}
Over the last thirty years water-scarcity has been the main factor restraining agricultural activity and the size of the nature reserve areas of the Kiskunság National Park in the Danube-Tisza Interfluve. Fluctuation of water resources affecting the plain areas in general is indicated by the decrease of the groundwater level, summarizing the effects of all the influencing phenomena. After that, the decreasing trend of groundwater level has been realized, studies aiming to determine the causes and the extent of the phenomenon have been carried out. Contrary to previous investigations, the present study does not analyze the different groundwater levels as time series. Instead, it deals with the spatial relationship of the measurements at certain moments of time using spatial semivariogram analysis on hydrographs of shallow groundwater data, in order to (i) analyse the spatial structure of the groundwater level monitoring well system and (ii) to recalibrate it. The results indicated a very strong, periodically changing correlation between groundwater level and elevation. Furthermore it was shown that the spatial variability of groundwater-level variations can be observed with half as many, more optimally arrenged stations as the existing ones.
\end{abstract}

Keywords: geostatistics, groundwater level, range, variogram analysis

\section{Introduction}

In the last thirty years, water-scarcity has been the main factor restraining agricultural activity and the size of the nature reserve areas of the Kiskunság National Park in the Danube-Tisza Ridge. This phenomenon has led to total or partial drying up of wetlands and degradation of certain habitats (BıRó,

\footnotetext{
${ }^{1}$ Department of Environmental and Landscape Geography, Eötvös Loránd University, H1117 Budapest, Pázmány Péter sétány 1/c. E-mail: kohanb@caesar.elte.hu

${ }^{2}$ Department of Physical Geography and Geoinformatics, University of Debrecen, H-4032 Debrecen, Egyetem tér 1.

${ }^{3}$ General Directorate of Water Management, H-1012 Budapest, Márvány utca 1/d. E-mail: szalai.jozsef@ovf.hu
} 
M. et al. 2013a,b; UjHázy, N. and Biró, M. 2013). Fluctuation of the volume of water resources affecting the plain areas is indicated by the decrease of the groundwater-level. This process summarizes the effects of all the influencing phenomena. The tendency of decreasing groundwater-level was first detected in hydrographs at the beginning of the 1980s. After that, several studies aiming to determine the causes and the extent of the phenomenon have been carried out (Major, P. and Neppel, F. 1988; Major, P. 1993; Szodfridt, I. 1993; Ladányi, Zs. et al. 2009, 2010).

Hydrographs are time series consisting of trend periodicity and noise, which are commonly analyzed separately. The study of smaller and larger decreases of ground water level and their spatial extension (e.g. mapping the groundwater level differences at certain moments of time) is a possible way of analyses (PÁlfai, I. 1994, 1996; RakonCzai, J. and Bódis, K. 2002; Szalai, J. et al. $2008,2011)$. A major part of this research-approach is the analysis of annual and multiannual periods of groundwater level fluctuation. Examples on the analysis of the former ones can already be found from the 1950s (UBELL, K. 1953; SzABó, Gy. 1959, 1960; RÉTháti, L. 1974; RóNAI, A. 1985; KováCs, J. et al. 2011a).

The peculiarity of the phenomena showing periodic changes is that the expected annual period may not recur, i.e. certain periods may not turn up. Annual periods are extremely important from an agricultural point of view, since the yield depends on precise planning. Therefore ground water level data should be assessed by methods that are capable of determining the existence and the possible non-existence of a period. Wavelet spectrum analysis is a reliable method to estimate the precise temporal fluctuation of periods (Kovács, J. et al. 2004, 2010.)

Some researchers applied multivariate data analysis techniques in order to determine the groundwater level fluctuation pattern of the studied area and the spatial distribution of the fluctuations (SzalaI, J. et al. 2011; KovácsSzékely, I. and Szalai, J. 2009; Ladányi, Zs. et al. 2009, 2010; Rakonczai, J. 2011). According to the new research trend of the last decade, groundwater level fluctuation is associated with subsurface flow systems (Mádlné SzôNYI, J. et al. 2005).

Previous approaches used a shallow ground water monitoring network as data source. It should be noted that samples taken from a monitoring system at a given point of time only represent one sample realization. A proper sample should reflect all the important characteristics of the statistical population and to allow the approximation of the unknown $z$ parameter's value in the $x, y$ coordinates of the sample area with adequate accuracy (Kovács, J. and Kovícs-SzÉKeLy, I. 2006a, b). Besides the above-mentioned conditions, it is required that the functioning of the monitoring system should be as economic as possible. The higher the variability of $z$ is within an $h$ distance, the denser the sampling should be. Variability can be described by means of several functions. 
In this particular work the semivariogram range is to be used for estimating spatial sampling range. Range is one of the main characteristics of the semivariogram, which is derived from the basic function of geostatistics, the variogram (MATHERon, G. 1965). In the Hungarian technical literature this function has been primarily used to determine the temporal sampling range of water chemistry parameters in order to estimate the adequate frequency of sampling (Kovács, J. et al. 2011b; 2012; Hatvani, I.G. et al. 2011, 2012a). Nevertheless, there are examples for spatial variogram analysis as well (Kovács, J. et al. 2005; Hatvani, I.G. et al. 2012b, 2014).

In the view of these studies, the main aim of the present research has been to not just analyse the different groundwater levels as simply time series; instead, it deals with the spatial relationship of the measurements at certain moments of time, in order to (i) analyse the spatial structure of the groundwater level monitoring well system and to (ii) recalibrate it, based on the results of the study.

\section{Materials and method}

\section{Location and characteristics of the studied area}

The study area is bordered by the Danube and Tisza rivers, the southern state border and Gödöllö Hills, so it is nearly $10,000 \mathrm{~km}^{2}$ area with featuring diversified landforms. The entire area consists of four geographical units: (i) an alluvial plain along the Danube, (ii) Danube-Tisza Ridge and (iii), Bácska Plain and (iv) Lower Tisza Plain (Hajdú-Moharos, J. and Hevesi, A. 1999; Mezősı, G. 2011a,b) (Figure 1).

The western border, the Danubian Plain is an alluvial cone flatland with a length of $240 \mathrm{~km}$ and a width of 20 to $25 \mathrm{~km}$, the former flood area of the river. The most complex landforms in the region can be found in the vicinity of Budapest. The higher areas feature terrace remnants, while the lower-lying parts were truly flood plains.

The terraces are made up by silty sand and aeolian sand, while the flood plains are made of fine-grain fluvial sediment. The southern part of the area is a perfect flatland intersected by microforms. The lower flood plains are covered by impermeable muddy-clayey sediment, while the higher flood areas are covered by overbank deposits and in some parts remobilized aeolian sand. Saline lakes are unique characteristics of the area. These were formed in the abandoned river beds partially filled with sediment without any outlets. A 10-20 m thick layer of gravel is located underneath the surface formations in the North, which continuously thickens toward to the South, and comes to the surface at the Kalocsa Plain (Kalocsai Sárköz) (Mezósı, G. 2011a,b). 


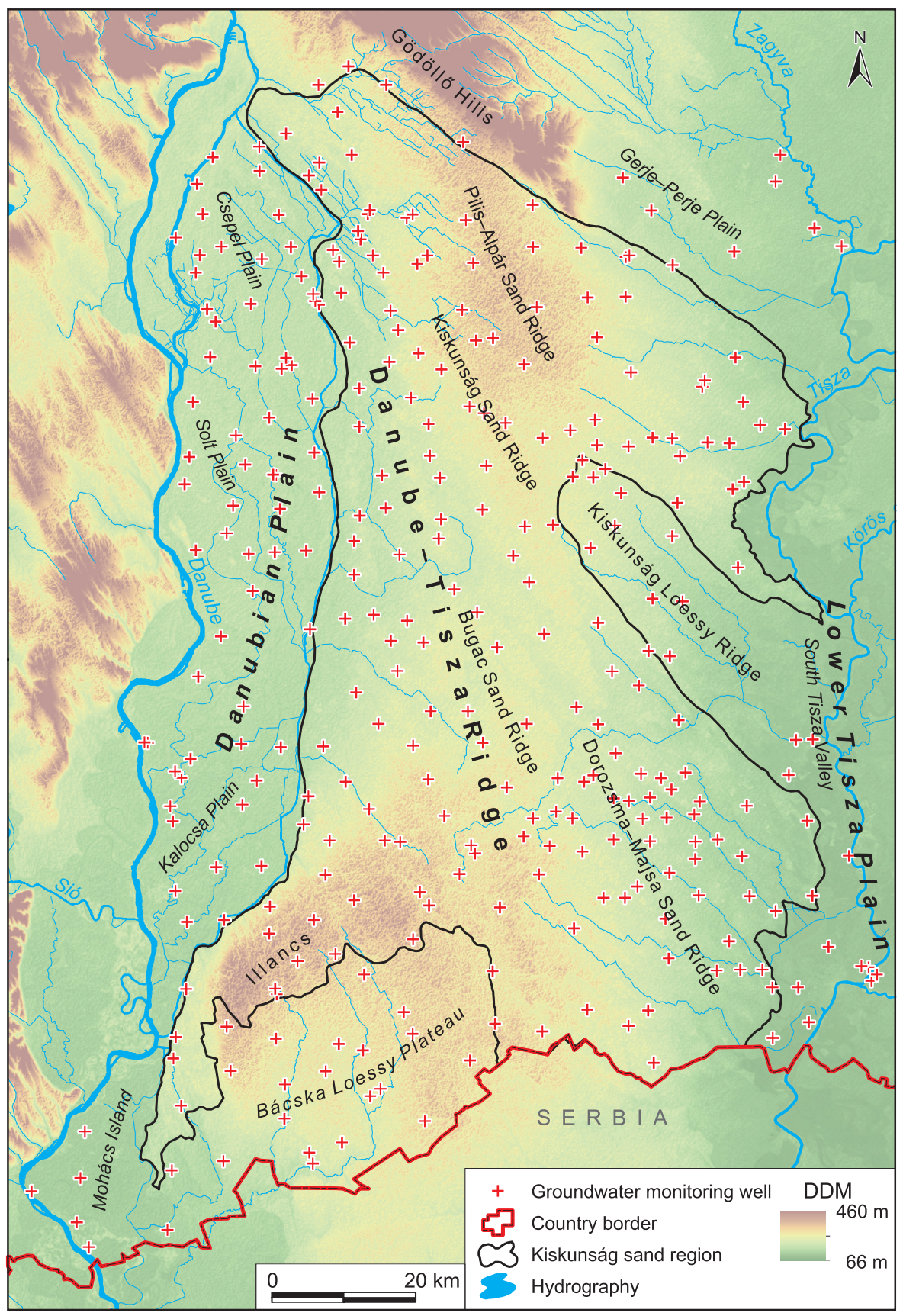

Fig. 1. The location and borders of the Danube-Tisza Interfluve and the shallow groundwater monitoring network 
The Bácska Loessy Plain located separately on the south-western part of the Danube-Tisza Interfluve, with an altitude varying between 100 to 175 $\mathrm{m}$ asl.. The area breaks off towards the west over the valley of the Danube with a steep edge, while in the west, towards the Danube-Tisza Ridge the transition is gradual.

The eastern border section of the Danube-Tisza Interfluve is called the Lower Tisza Plain featuring a very low-lying area of 79 to $85 \mathrm{~m}$ asl. with a Holocene alluvial flatland. Towards the east, its surface is diversified by loop lakes, ox-bow lakes and formations created by wind activity with eroding edges.

According to Biró, M. et al. (2009) the centre of the Danube-Tisza Interfluve is the Danube-Tisza Ridge with an altitude of 100 to $130 \mathrm{~m}$ asl., stretching from Gödöllő Hills to Bácska Plain covering a total area of 7,400 km². The surface forms have been mainly created by the wind and only secondly by water. The curved formations located in the western part of the region have been formed by the side branches of River Danube. These areas were flooded by the river and were filled up by fine-grain sediment. Diversified sand forms were formed owing to the aeolian surface-forming activity. The extensive flat or slightly undulating plains are broken up by island-like sand-dunes. In general, these sand dunes are only a few $\mathrm{km}$ wide, but some of them have a diameter of over $10 \mathrm{~km}$.

The areas covered by aeolian sand are characterized by mesoforms such as: wind grooves, hummocks and remnant ridges, and even parabola dunes (KIss, T. and ToRnYÁnsZKI, É. 2006). Wet and boggy areas often without outlets, lakes and meadows - temporary covered by water - were formed in the grooves between the sand dunes (LóKI, J. 1999; MezôsI, G. 2011a). Underneath the boggy areas very often limestone deposits were formed with a total thickness of 20 to $30 \mathrm{~cm}$.

\section{The geological characteristics of the Danube-Tisza Interfluve and the lack of water}

The Neogene sediments of the area do not form a cohesive aquitard, thus the region is characterized by a unified water flow system. Two flow regimes can be distinguished: (i) gravity driven flow regime with precipitation as main water source and (ii) over pressured saline flow regime (MÁDLnÉ SzóNYI, J. et al. 2005). In the ridge region of the Interfluve (i.e. recharge zone) the infiltrated water flows towards the Danube and Tisza valleys (flow regions) due to differences in the altitudes of the two regions. Gravity driven meteoric waters are "hydraulically supported" by deep waters, but the latter are upwelling locally through migration routes such as faults on the Ridge. 
Water resources coming from the Ridge through the gravity driven flow reach the surface at discharge areas, as they move towards the Danube valley. The major part of these waters are hydraulically trapped or accumulated in groundwater reservoirs. (MÁdLné SzŐNYI, J. and TóTH, J. 2007). The local and intermediary flow systems are hierarchically structured on the regional water flow system of the Danube-Tisza Interfluve. In the case of the local water flow systems, the direction of water flow is determined by the geomorphological characteristics of the region. In the case of sand dunes, infiltration of rainwater can be observed, while the gaps between adjacent sand dunes are characterized by water discharge. On a local level these processes can be considered a system.

In the Danube-Tisza Interfluve precipitation surplus was experienced up to the middle of the 1960s, followed by a stagnation period until the middle of the 1970s. As a result of the surplus waters the ground water level has been increased. Saline flat areas and deflation coves were inundated very often. At this time (i) the drainage water channel system construction was completed, and (ii) larger areas were planted with tree species with high water demand, mostly with poplar.

From the beginning of the 1970s to the middle of the 1990s the precipitation level dropped below the climatic mean, a shortage of nearly $1000 \mathrm{~mm}$ in precipitation was experienced in the area.

As a result, ground water level started to drop, significant portion of the former lakes and boggy areas dried up (Major, P. 1994; Liebe, P. 1994). During this time extensive ground water exploitation took place mostly for irrigation purposes, which also contributed to the further reduction of ground water level.

The exact amount of water exploited in the territory of the investigated area is unknown. The shortage of rainfall was mitigated by the middle of the 1990s, as a result the intensity of ground water level dropping slowed down and in certain areas the water table started to rise (SzalaI, J. 1996). Besides the lack of precipitation, the fluctuation of the groundwater level is influenced by the exploitation of artesian water, too. At the beginning of the 2000s, with the decrease of the exploitation of artesian water, the pressure heads began to rise (Liebe, P. 1994).

\section{Preparation of groundwater-level data}

Four Water Management Directorates have a system for detecting groundwater level comprising 398 groundwater wells. The database contains data from shallow-groundwater wells that have ceased their activity for different reasons. One of the reasons can be the drop of groundwater-level in the vicinity 
of a given groundwater well, when the water level reached the bottom screening section, the well theoretically aridified and it became useless for regular measurements (Szalai, J. and NAGY, Gr. 2006).

Data preparation was conducted on groundwater level time series with different lengths and quality. Besides filtering the data, hydrographs have been derived which helped to spot clearly incorrect or incomplete data (obvious typos, date entry mistakes etc.). Some hydrographs had to be modified since their pipe rim was changed. If such mistakes could not be corrected in an obvious way, the data sets were discarded.

Besides GIS-based solutions, the visual presentation of the data sets had an important role too. The first step of spatial error filtering comprised visual presentation. Using Golden Software Surfer 11 and Scripter isoline maps were created by linear interpolation for 60 months. The isoline maps showed the outstanding values of the data sets. The values corresponding to the given values were identified in the data source.

After the visual interpretation, the rasters were interpolated from the remaining points and cross validation was carried out. In cases where the difference between estimated and measured values were outstanding, further investigations were carried out to determine whether they were due to extreme values or measurement errors.

Measurement errors were corrected when it was possible or the sampling sites were omitted from further analysis. After correcting and filtering the data, 321 groundwater level monitoring wells were left for analyses (Figure 1). The spatial distribution of the groundwater monitoring wells is uneven. The distance between the closest groundwater monitoring wells is $3.61 \mathrm{~m}$ while the largest distance is $12 \mathrm{~km}$. The average is $8,186.56 \mathrm{~m}$ and the standard deviation is $2,645.74 \mathrm{~m}$.

Sixty sample realizations were chosen from the monthly averages of the measurement period between 1980 and 2010 to form the basis of the variograms to present the spatial correlation between the data sets. Data measured for every January, April, July and October from every second year were chosen, in order to achieve the 60 sample realizations.

Thus, the annual periods could be followed, which is a key characteristic of groundwater level. Moreover, it is known that analysing every second year is enough to observe the fluctuation of time series (SHANnON, C.E. 1949). In the period of 2002-2004 the highest number of wells reached 289, but until the 1990s this number was less than 200, with a minimum of 188 functioning wells. As an average it can be stated that the time series of only 234 wells could be used.

An average of 44 months was available out of the total 60.53 monitoring stations (16.5\%) had complete data sets. The median and standard deviation wer 51 and 16.87, respectively. 
Semivariogram function derived from the variogram are the most suitable function to analyze the spatial dependence of the groundwater level data. The function can be described the following way (Füst, A. 1997; Molnár, S. and Füst, A. 2002; MolnáR, S. et al. 2010): Let $Z(x)$ and $Z(x+h)$ be the values of a parameter sampled at distance $|h|$ from each other. The variance of the difference of $Z(x)$ and $Z(x+h)$ is

$$
D^{2}[Z(x)-Z(x+h)]=D^{2}[Z(x)]+D^{2}[Z(x+h)]-2 \operatorname{COV}[Z(x), Z(x+h)]
$$

In the case of samples taken from the same population (stationarity) we could assume that

$$
\begin{gathered}
D^{2}[Z(x)]=D^{2}[Z(x+h)], \text { so that } \\
D^{2}[Z(x)-Z(x+h)]=2 D^{2}[Z(x)]-2 \operatorname{COV}[Z(x), Z(x+h)]=2 \gamma(h)
\end{gathered}
$$

The function $2 \gamma(h)$ is called the parameter's variogram, while $\gamma(h)$ is its semivariogram. If we introduce the simplified notation $D^{2}[Z(x)]=D^{2}(x)$, and $\operatorname{COV}[Z(x), Z(x+h)]=g(h)$, then $\gamma(h)=D^{2}(x)-g(h)$. The semivariogram could be calculated by the Matheron algorithm (Matheron, G. 1965): where $N(h)$ is the number of pairs within the lag interval $h$.

In practice, $Z(x i) \geq 0(i=1,2, \ldots, n)$ and $D^{2}[Z(x)] \geq g(h) \geq 0$, so that theoretically the semivariogram can only take values from the $0 \leq \gamma(h) \leq D^{2}[Z(x)]$. The most important properties of the function are the follows (Figure 2):

(i) If the function does not start from the arbitrary point of the coordinates $\left(C_{0}>0\right)$, it will be called "nugget effect". The value $C_{0}$ of the semivariogram at the origin provides information of the sampling error.

(ii) If the semivariogram does not have a rising part, the points of the semivariogram will align above the abscissa parallel to it. A semivariogram such as this is called of a nugget effect type. In this case no range can be estimated, i.e. the sampling frequency is insufficient.

(iii) The level at which the variogram stabilizes is the sill $\left(C+C_{0}\right)$; it is equal to the variance for stationary processes. The value $C$ itself is the reduced sill.

(iv) Range is the distance within the samples still have an influence on each other (Webster, R. and Oliver, M.A. 2007).

If $\gamma(h)$ is an increasing function (if $h \rightarrow \infty$ then $\gamma(h) \rightarrow \infty$ ), the parameter is non-stationary Kovícs, J. et al. 2012).

Empirical semivariograms can be approximated by many theoretical functions. (Deutsch, C.V. and Journel, A.G. 1992; Wackernagel, H. 2003). The estimation of sampling frequency using variograms is based on the range. 


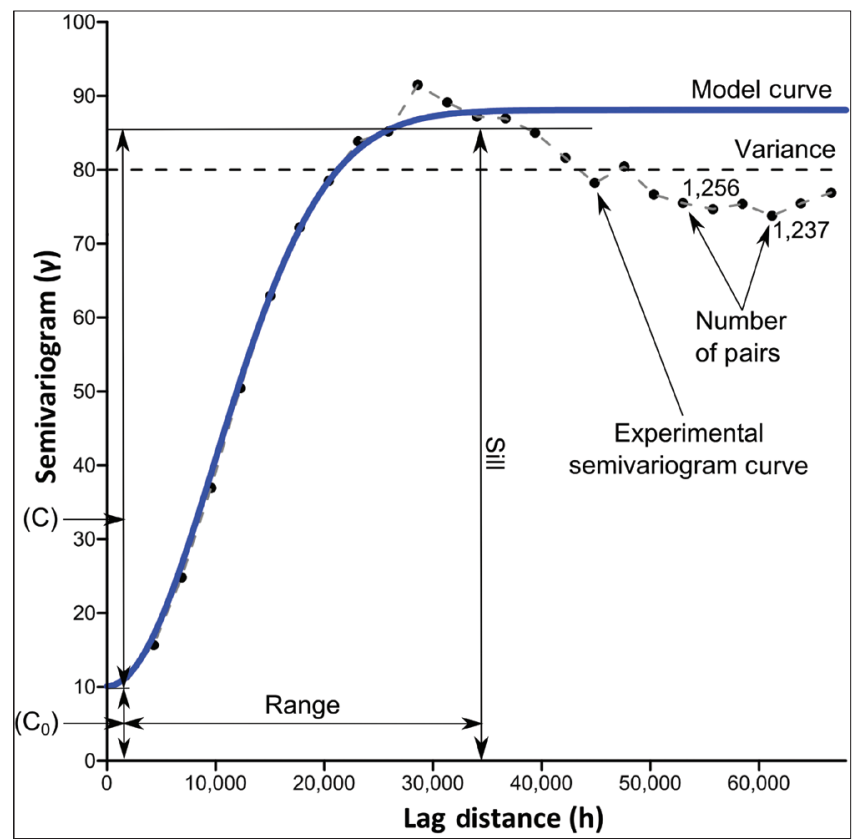

Fig. 2. The properties of the semivariogram

Samples that are outside the range are uncorrelated. If we want to find adequate information about the circumstances and processes that led to the depletion of the groundwater, the sampling network should be optimized in a way so that is unifying spatial ranges (i.e. areas defined by ranges around the sampling points) we could cover the whole sampling site (Füst, A. and GeIgER, J. 2010; FüsT, A. 2011). If the range of a studied parameter is undirectional, then the phenomenon is isotropic and the spatial range will be circular. Otherwise anisotropy is produced and the special range will be of an elliptic nature. If parameters are isotropic, the sampling points should be placed in a grid composed of squares or equilateral triangles, while if parameters are anisotropic sampling points, they should be located in a grid composed of isosceles triangles.

In order to gain information referring/covering to the whole area, it is insufficient to only have a square grid with an edge length that is twofold of the estimated range. On the contrary, the edge length should be $a \sqrt{2}$ (Figure $3 .$, a) in case of square grid and $a \sqrt{3}$ (Figure 3., b) in case of triangular grid. In the case of an ellipse range area the same values can be approximated by an edge length of $a \sqrt{2}$ and $b \sqrt{2}$ in the case of a rectangular grid, while $a \sqrt{3}$ and $b \sqrt{3}$ in the case of an isosceles triangular grid. 
Two adjacent equilateral triangles form a rhombus while two adjacent isosceles triangles form a parallelogram (Figure 3., c). It is clear that these networks are much more favorable than the ones formed of squares or rectangles, as using these networks a larger area can be covered with the same number of sample points. Thus the number of sampling points necessary to cover the sample area is $23 \%$ less.

In case of rectangular and rhomboid grids the side lengths of the cells should be adjusted to the direction of the smallest and largest ranges of the parameter analysed (Füst, A. 1997).

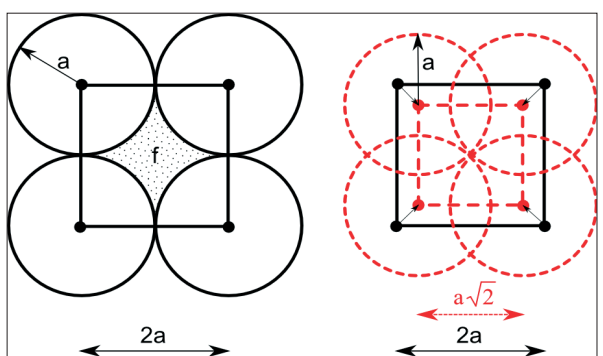

a)

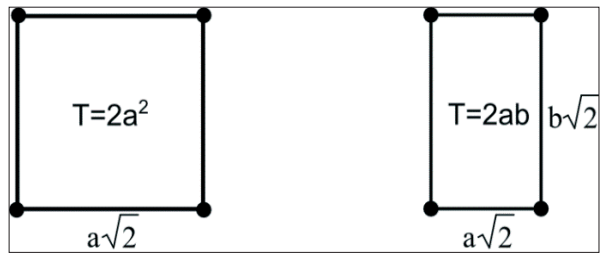

c)

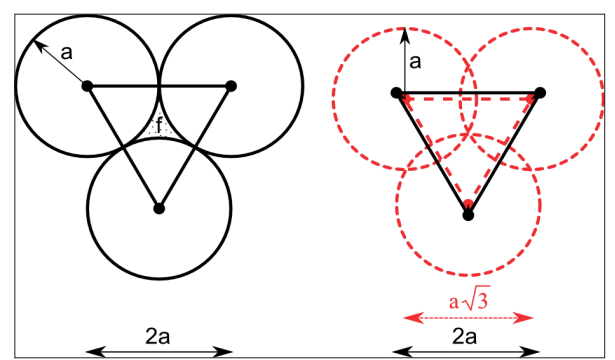

b)

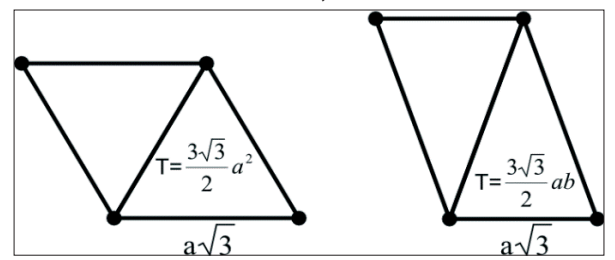

Fig. 3. The relationship between range and sampling network in the case of square grid (a); between range and sampling network in the case of triangular grid (b); Comparing the configuration of the sample networks (c) (based on Füst, A. 1997)

Preliminary data analysis, representative examples from the empirical semivariograms of the sample area

Variogram analysis was carried out on the pre-processed data series. As the same operation had to be performed sixty times in the case of each chosen point in time, therefore a script was written in Scripter in order to batch the operation sequence. The script generated $\mathrm{n}$ variograms based on the $x, y, z_{1}, z_{2^{\prime}}$ $\ldots z_{n}$ structured ASCII type input files and on the set parameters. The following parameters were adjustable: maximum lag distance, number of lags, direction of pairs, tolerance, the detrend type, the * dat files comprise the $x, y$ coordinates of the variograms $(h, \gamma)$, while the ${ }^{*}$.jpg file includes graphic representation of 
the $n$ variograms (http://gis.elte.hu/geostat). First, the program was compiled using the default settings of the Surfer, specifically the maximum lag distance was set to $68,000 \mathrm{~m}$, the number of lags 25 , the direction of pairs is $90^{\circ}$ (undirectional). In this case trend has not been removed. Each of the obtained functions reached the sill at a $40 \mathrm{~km}$ long range and a variance of $200 \mathrm{~m}^{2}$.

Since area is part of a ridge and the surface of the groundwater moreor-less adjusts to the topographic surface, therefore the anisotropy of the parameters is assumed. As the number of elements in the sample realisations is high enough to calculate directional empirical semivariograms, these were computed in the four main directions (W-E, NW-SE, N-S, NE-SW). The script was computed with the following modified settings: the tolerance was set to $30^{\circ}$ and the direction was set to $0^{\circ}(\mathrm{W}-\mathrm{E})$. Then the operation was carried out with the same tolerance $\left(0^{\circ}\right)$ and the direction being $45^{\circ}$ (NW-SE), $90^{\circ}(\mathrm{N}-\mathrm{S})$ and $135^{\circ}(\mathrm{NE}-\mathrm{SW})$. Studying the obtained 240 functions the previous assumptions have been proved to be correct.

The preliminary variograms were calculated from the data of October 2006 to explore whether the functions have different ranges and different variances (anisotropic structure). The most peculiar semivariogram was related to the N-S direction, as it showed a monotonic increase that can be traced back to trend-like changes.

If the trend subtraction proved to be successful, then - after subtracting an adequate order trend - the semivariogram of the residuals will be stationary and the variance can be determined and thus the range, too (Füst, A. 1984). Therefore as a next step, linear trend was subtracted using the same settings. The results were the same, thus in the following step the quadratic trend was subtracted. Unlike the linear trend, the $X$ and $Y$ direction trends provide a model with an adequate approximation to the general inclination of the Danube-Tisza Ridge. Thus after the subtraction of the quadratic trend we could determine the range in each of the four directions. This was automatically carried out onwards.

After these steps, the directional semivariograms were merged to facilitate the recognition of the anisotropy and the definition of the range. Moreover, a semivariogram surface was created for the same reason (Figure 4). Based on the above mentioned semivariograms, the anisotropy direction is NNE-SSW while the range is approximately 20 and $30 \mathrm{~km}$.

\section{Results and discussion}

\section{Determining the smallest spatial structure}

To examine the phenomena - describable with the smallest spatial structure - governing the groundwater level, the distance among the monitoring wells 


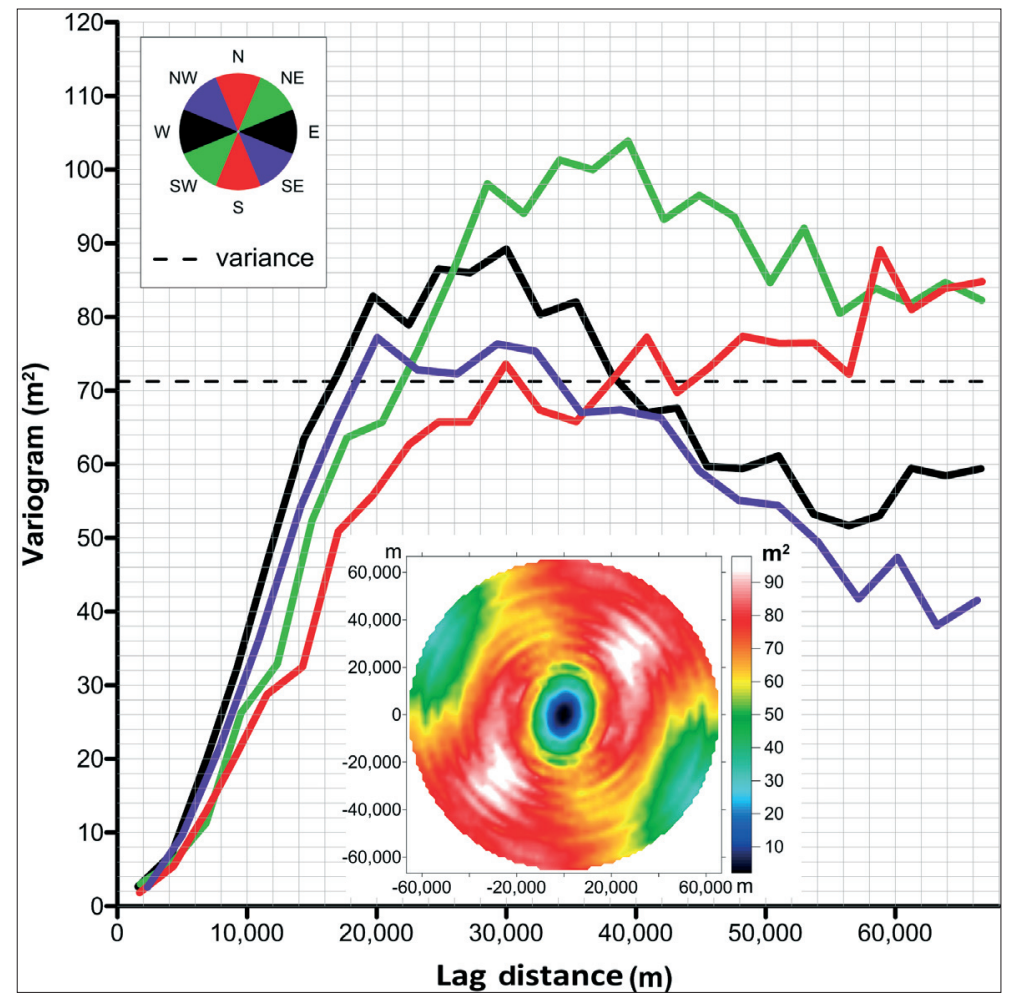

Fig. 4. Regional semivariogram-surface derived for the groundwater level data measured in October 2006 visualized by colour ramp

has to be shorter than the characteristic action radius of the monitored process. Therefore, the smallest range has to be estimated from the empirical semivariograms.

In order to recognize the assumed smallest ranges, the resolution of the semivariogram has to be increased. To achieve this either the maximum lag distance could be decreased or the number of lags could be increased. Hence, the script was modified in the following way: maximum lag distance was decreased to $34,000 \mathrm{~m}$ while the number of lags remained 25; thus the achieved resolution doubled compared to the original situation. At this resolution more than one range became noticeable (Figure 5., a).

The presence of multi-sill structures can be explained by different processes building up on one another. In such cases fitting of the multiple sill semivariograms should be carried out. However, the currently available applications do not facilitate this process. Therefore the smallest range could only be determined by manually fitting a theoretical model to the empirical semivari- 
ogram. Moreover, the direction of the anisotropy has changed, too. While on the regional level, the direction of the major axes was NE, on a local level its direction has changed to SE (Figure 5., b). In the case of the sample realizations with data available from a minimum of 250 ground water level monitoring wells, the smallest range appeared at a lag distance of 3,000 meters.

However, in the case of such a small search radius, the number of pairs was insufficient from a statistical point of view. Therefore, in the case of this particular semivariogram (Figure 5., b) the smallest range was determined at the second sill with a value of $6 \mathrm{~km}$ in the NE direction, while in the SE direction the smallest range was $14 \mathrm{~km}$.

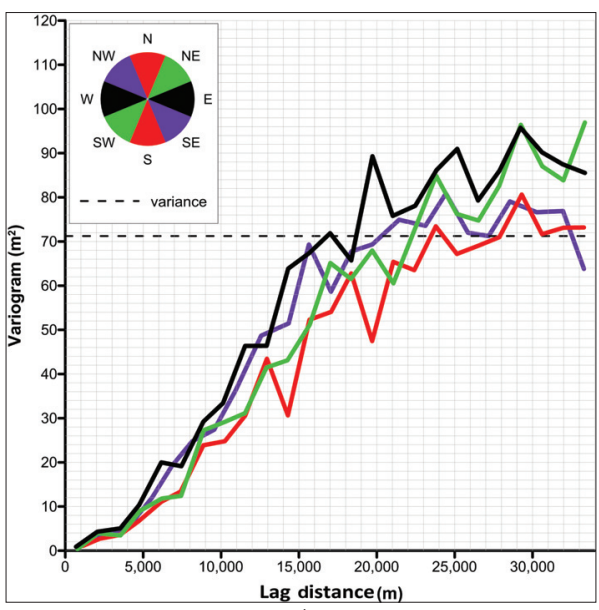

a)

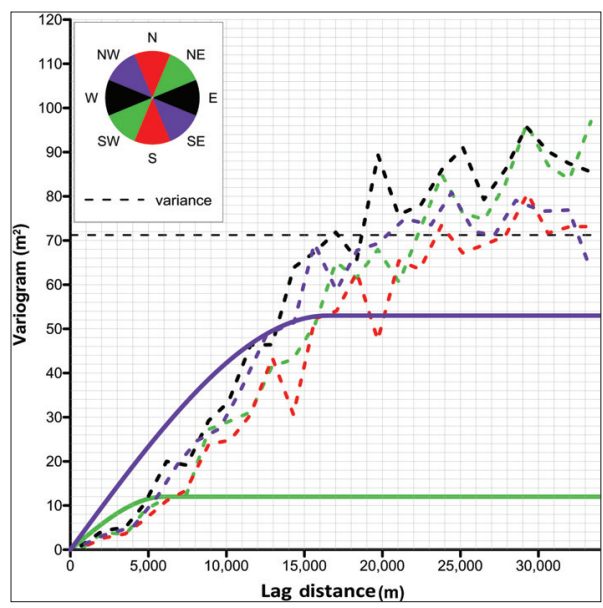

b)

Fig. 5. The four directional empirical semivariograms based on data measured in October 2006 with doubled resolution (a); Spherical theoretical semivariograms visualised together with the semivariograms indicating the smallest range at $\sim 2,500 \mathrm{~m}$ and the ones significant base on the number of pairs at $\sim 6,000 \mathrm{~m}$ and $\sim 14,000 \mathrm{~m} \mathrm{(b)}$. The colours of the semivariograms correspond to the direction in the inset pie-chart

Applying this method, the data measured in other years gave the same results with a standard deviation was $16.6 \%$, consequently the range was reduced with the value of the standard deviation, to ensure the full coverage of the area. In the forthcoming analyses, the range value of 5 and $11.67 \mathrm{~km}$ were used.

\section{Outlook on the diversity of relief and shallow groundwater}

The example of the Fülöpháza sand dune region is presented to show explicitly that the shallow groundwater fluctuation is the main governing factor regarding the first sill. 
The proportion and the direction of the axis basically overlap, while the ranges are smaller than parameters defined in the case of groundwater (Figure 6). It can be assumed that the smaller ranges exist in the case of groundwater levels, too, but especially in these areas with a variable relief, the distance between data pairs is larger than the assumed minimal range. Based on the above-mentioned observations, it is assumed that in the 1980s and in the first part of the 1990s, in certain areas, the sampling network was not dense enough to enable tracing of the groundwater changes determined by the meso-forms. In other areas it was too dense. In the subsequent years more groundwater level detection wells were established, so blank spots disappeared but at the same time the proportion of overrepresented areas increased.

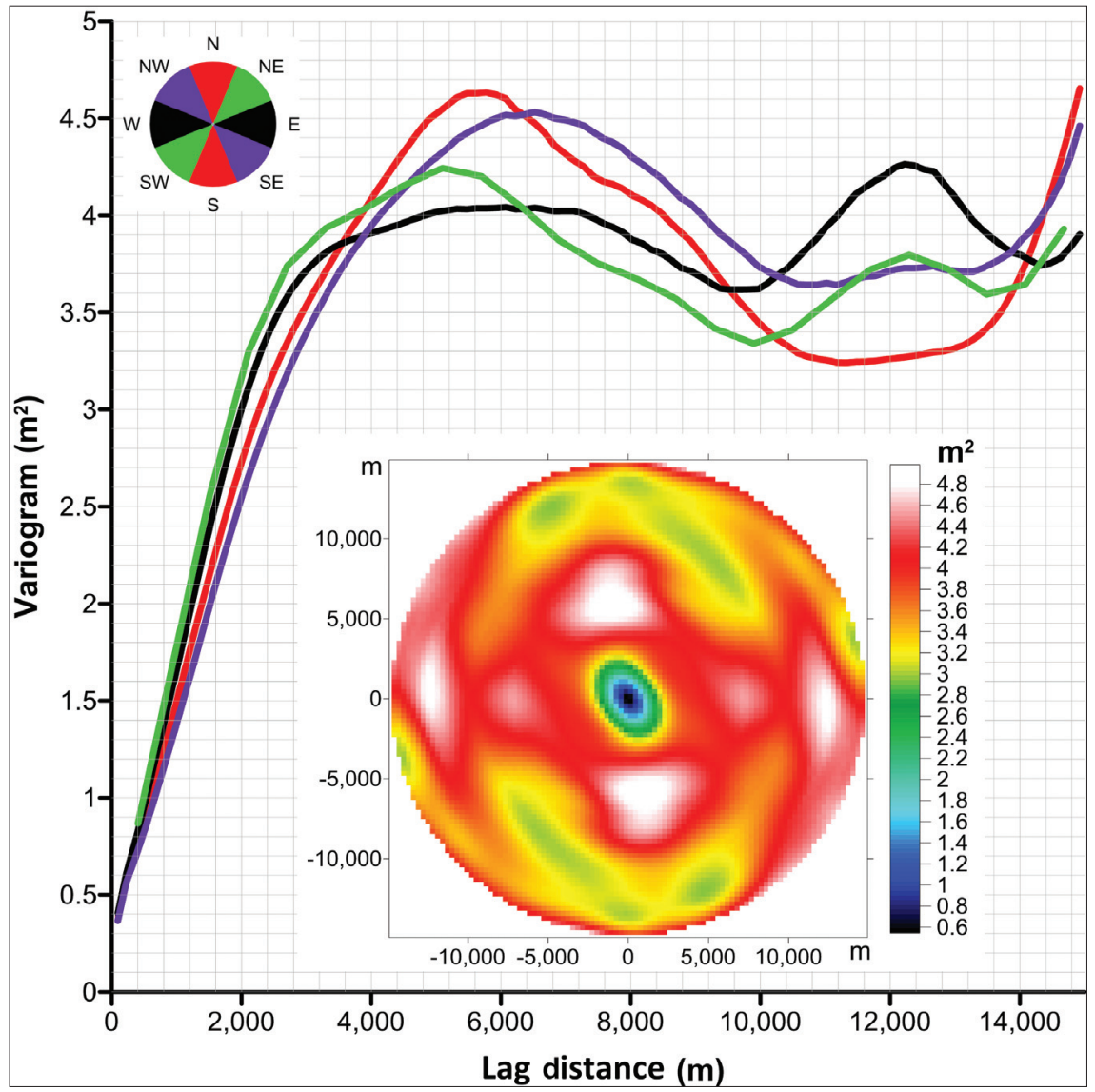

Fig. 6. The four directional empirical semivariograms of the Fülöpháza dune region in the four main directions corresponding to the colours of the inset pie-chart (upper left) and the surface of the variogram (bottom right) 


\section{Spatial range analyses}

Using the coordinates of groundwater level monitoring wells that disposed of data in the studied period (1981-2010), the previously determined spatial ranges (ellipses) were plotted. It helped to determine the extent of optimal groundwater level monitoring well network with adequate accuravy in the Danube-Tisza Interfluve in the different periods. By this way, it became possible to find out that there were unmonitored areas that had not been covered by the spatial ranges of any of the existing groundwater monitoring wells, thus information was lacking regarding these areas. Additional important aspects regarding the present and future monitoring plans are (i) whether the existing groundwater level monitoring well network fully covers the area of the Ridge, and (ii) which are the areas where the network is too dense.

October 1982 was the month when the smallest number of monitoring stations were available (Figure 7., a), while the most favourable case occurred in October 2010 (Figure 7., b) with the highest number of wells operating in the system. It is clear that the coverage was much sparse in 1982.

On the one hand the most outstanding pattern is the extent of the areas with incomplete data sets, the so called blank spots. The most predominant is the white spot in the Kéleshalom, Jánoshalma and Borota regions, where the reduction of the groundwater level is the most significant up to

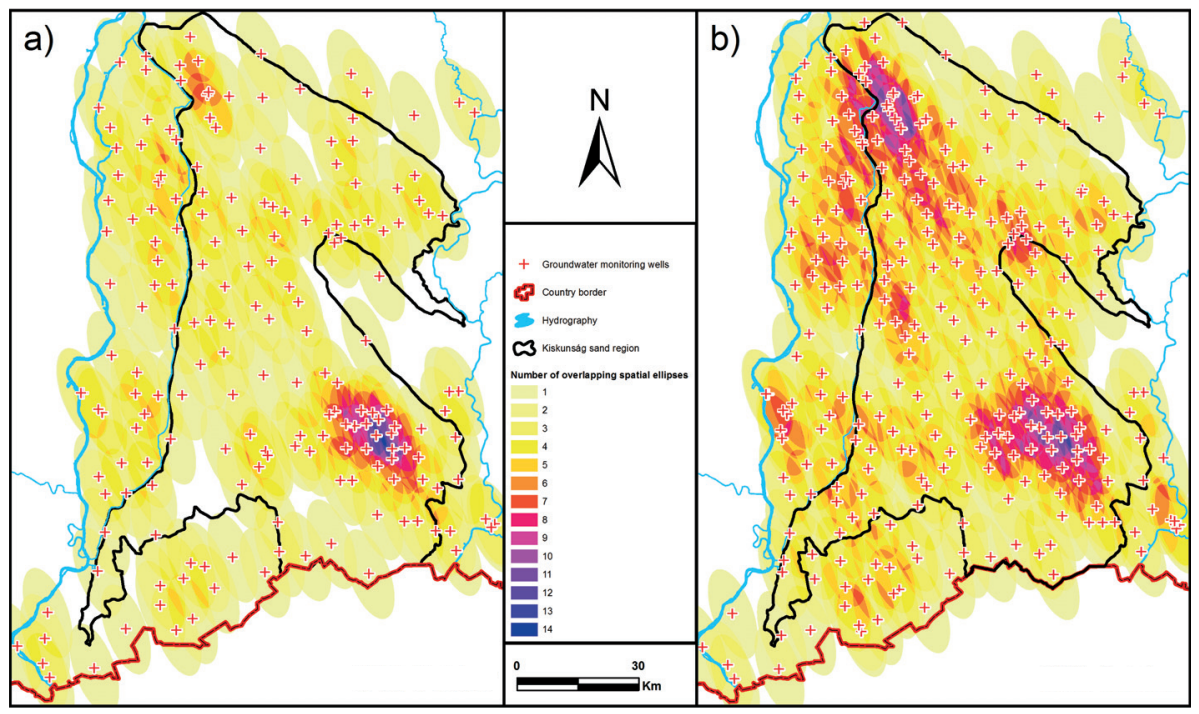

Fig. 7. The number of overlapping spatial range ellipses in the Danube-Tisza Ridge in October 1986 (a), and in October 2010 (b) 
this day. Moreover, significant blank spots exist in the Baja, Bátmonostor and Fülöpjakab, Bugac regions as well. On the other hand the network is needlessly dense around Kömpöc and Balástya, where some areas are covered by the spatial ranges of 14 monitoring stations.

The map of October 2010 (Figure 7., b) shows a situation similar to the present conditions. The number of blank spots is negligible in the area of the Kiskunsági sand region, which is important from the point of view of groundwater level depletion. In the case of this sample realization the only area with incomplete data sets is that of Mórahalom. On the contrary, the number of areas that are covered by multiple monitoring wells increased. Furthermore, the number of monitoring stations around Kecskemét and Dabas has increased. Figure 7 indicates the two extreme values, but it can be generally stated that if the available data is scarce then the spatial density of the network will be insufficient and vice versa. This was mainly true for the 1980s and the first half of the 1990s. From the second half of the 1990s, with the increase of the monitoring stations that could be used in the analyses, the number of blank spots has minimalized, and the proportion of the areas that were covered by 10-14 monitoring points has increased.

An idealised groundwater level monitoring well network has been obtained on the bounding box of the Kiskunság sand region (Figure 8) based on the relationship between the ranges determined using the multiple sill directional empirical semivariograms and the research network described above. This network can be established with a minimal number of wells. The network functioning at the end of 2010 is generally much denser than the ideal measuring network plotted based on the ranges, while there are still areas characterized by the absence of data, as shown before.

Obviously, this is a theoretical, geometric model, optimized to the higher areas of the Danube Tisza Interfluve mainly affected by aridification. The state border had to be taken into consideration while other objective restraining factors (e.g. paved roads, gravel pits) were not considered.

In order to expand the model to the lower areas bordering the Ridge, further intermediate points need to be determined, so that each intersection would lie on the territory of the Danube-Tisza Interfluve and the spatial range ellipses placed around these points would fully cover the territory between the two rivers. Thus the ideal location of the monitoring points cannot be determined only by a geometric model.

\section{Conclusion}

The main purpose of the study was to estimate the minimal number of monitoring wells that are necessary to track the spatial processes that can be followed with 


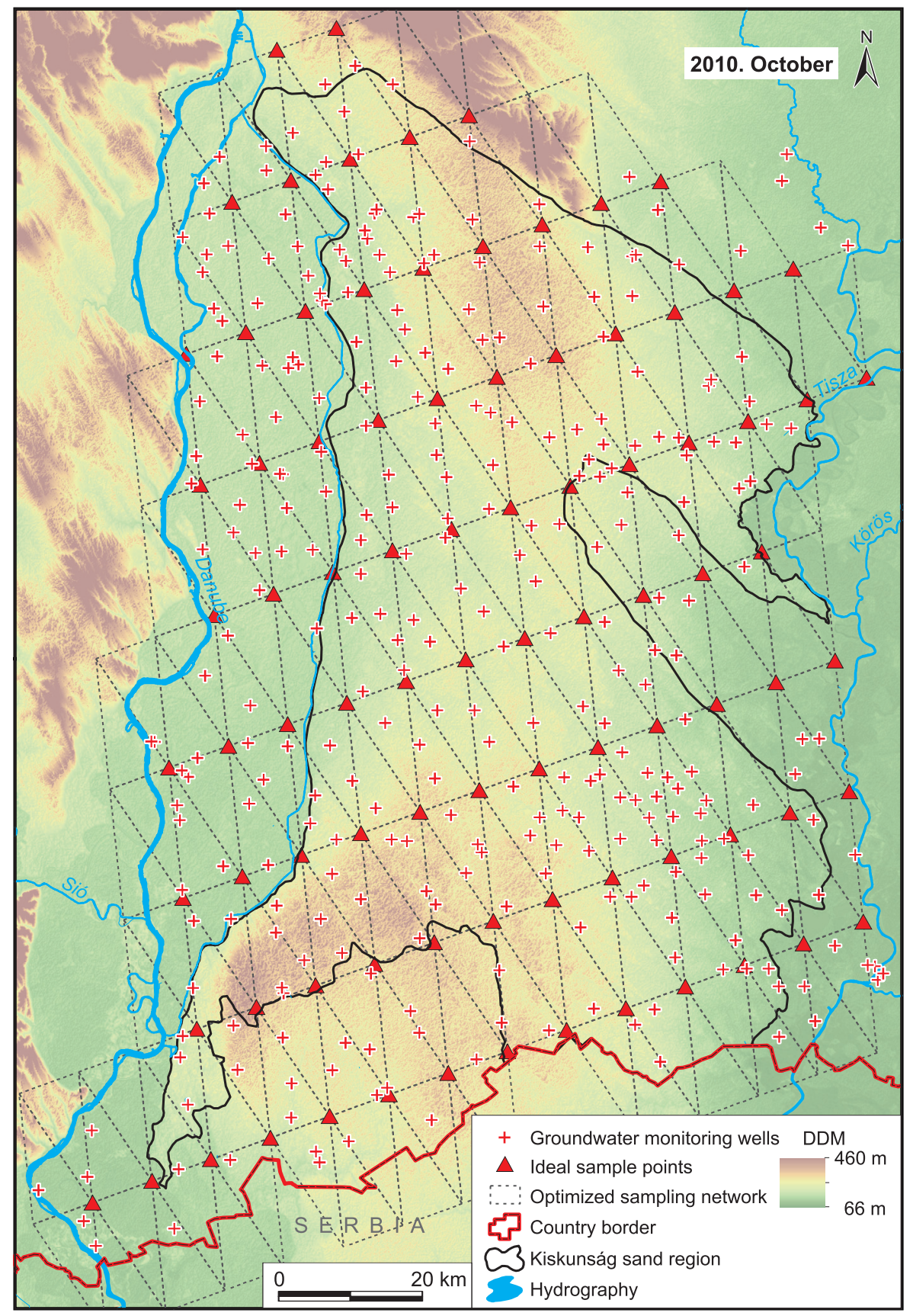

Fig. 8. The relationship between proposed sampling network and the monitoring wells in October 2010 in EOV projection 
the existing network, given that the monitoring wells are located in an adequate way. The spatial structure of groundwater was analysed with the aid of directional empirical semivariograms at the Danube-Tisza Interfluve (1981-2010).

The conclusion has been reached that the multiple sill structure indicated by the semivariograms originates from the geomorphological units with different scales (Kiss, T. and ToRnYánsZKI, É. 2006).

In the largest regional structure characterized by a range around 20 and $30 \mathrm{~km}$ and anisotropy with a direction of NNE-SSW. The direction of the axis linking the highest parts of the Ridge was determined, while the ranges reflect the variability related to the alluvial cone. The smallest ranges identified, were at the second sill with a value of 5 and $11.67 \mathrm{~km}$.

The correlation between the groundwater level and the elevation is periodically changing, but it is very strong. The more variable the relief of the area, the higher the variability of the groundwater level will be. Thus, if one wants to determine the smallest spatial structure of the groundwater level fluctuation during monitoring network recalibration, the geomorphological characteristics of the area have to be taken into account.

According to the results, the spatial variability of groundwater-level variations can be observed with half as many stations as the existing network if they were optimally arranged. By establishing a couple of new detection wells or repositioning a few of the existing ones, even finer spatial processes could be monitored, thus the progression of the depletion could be interpreted in a more profound way.

Acknowledgement. The research of Balázs KонÁN was supported by the European Union and the State of Hungary, co-financed by the European Social Fund in the framework of TÁMOP 4.2.4. A/2-11-1-2012-0001 ‘National Excellence Program’.

\section{REFERENCES}

Biró, M., Lelleiné Kovács, E., Kröel-Dulay, Gy. and Horváth, F. 2009. A Kiskunsági homokvidék tájökológiai térképe (Landscape ecologycal map of the Kiskunság sand region, Hungary). In Válogatás az MTA Ökológiai és Botanikai Kutatóintézete kutatási eredményeiból. Eds: Töröк, K., Kıss, K.T. and KertÉsz, M. Vácrátót, MTA Ökológiai Kutatóközpont Ökológiai és Botanikai Intézet, 29-35.

Biró, M., Czúcz, B., Horváth, F., Révész, A., Csatári, B. and Molnár, Zs. 2013a. Drivers of grassland loss in Hungary during the post-socialist transformation (1987-1999). Landscape Ecology 28. (5): 789-803.

Biró, M., Szitár, K., Horváth, F., Bagi, I. and Molnár, Zs. 2013b. Detection of long-term landscape changes and trajectories in a Pannonian sand region: comparing land-cover and habitat-based approaches at two spatial scales. Community Ecology 14. (2): 219-230.

Deutsch, C.V. and Journal, A.G. 1992. GSLIB Geostatistical Software Library and User's Guide. New York-Oxford, Oxford University Press, 363 p. 
Füst, A. 1984. Adalékok az instacionárius paramétermezők kutatási optimumának meghatározásához (Improvemements for non-stationary parameterization in deteremining the exploration optimum). BKL-Bányászat 32. (1-4): 93-112.

Füst, A. 1997. Geostatisztika (Geostatistics). Egyetemi jegyzet. Budapest, Eötvös Kiadó, 427 p.

Füst, A. 2011. A természeti folyamatok monitoring hálózatainak tervezése és működtetése (Planning and operating monitoring systems of natural processes). BKL-Bányászat 144. (2): 19-25.

Füst, A. and Geiger, J. 2010. Monitorigtervezés és -értékelés geostatisztikai módszerekkel I. Szakértői véleményen alapuló, "igazoló" mintázás geostatisztikai támogatása (Monitoring planning and evaluation using geostatistics, I. Geostatistical support for verification sampling based on professional opinion). Földtani Közlöny 140. (3): 303-213.

Hajdú-Moharos, J. and Hevesi, A. 1999. The land that is Hungary - geology, geography and cartography of Hungary and its surroundings. In Pannon Encyclopaedia. Ed. Karátson, D., Budapest, Kertek 2000 Publishing House, 274-284.

Hatvani, I.G., Kovács, J., Barcza, M., Kovácsné SzéKely, I., JaKusch, P. and Bernáth, Gy. 2011. Adatelemző módszerek alkalmazásának feltételei és lehetőségei a felszíni és felszín alatti víz védelmében (The requirements and possibilities of applying data analysis methods in surface- and sub-surface water protection). In A fenntartható fejlödés, valamint a környezet-és természetvédelem összefüggései a Kárpát-medencében. Eds. BunYevácz, J., Csonka, P., Fodor, I. and Gálosi-Kovács, B., Pécs, MTA Pécsi Akadémiai Bizottság.

Hatvani, I.G., Kovács, J. and KorponaI, J. 2012a. Mintavételezési gyakoriság optimalizálása variogram függvénnyel a Kis-Balaton Vízvédelmi Rendszer példáján (Optimization of sampling frequency using variograms on the example of the Kis-Balaton Water Protection System). Természetvédelmi Közlemények 18. 202-210.

Hatvani, I.G., Reskóné, N. M., Kovácsné Székely, I., Tanos, P., Korponai, J. and Kovács, J. 2012b. Determining the temporal sampling frequency of Kis-Balaton and the spatial sampling frequency of Lake Velence (W Hungary) using variograms. In $\mathrm{CMA} 4 \mathrm{CH}$ : Use of Multivariate Analysis and Chemometrics in Cultural Heritage and Environment. Ed. Visco, G., Rome, Marco Valerio Editore. 62-63.

Hatvani, I.G., Magyar, N., Zessner, M., Kovács, J. and Blaschke, A.P. 2014. The Water Framework Directive: Can more information be extracted from groundwater data? A case study of Seewinkel, Burgenland, Eastern Austria. Hydrogeology Journal 22. (4): 779-794. DOI: http://dx.doi.org/10.1007/s10040-013-1093-x (available online).

Kiss, T. and TornYánszKI, É. 2006. Futóhomok területek geomorfológiai vizsgálata a Duna-Tisza közén (The geomorphological analysis of the quicksand regions in the Danube-Tisza Interfluve). In III. Magyar Földrajzi Konferencia Tudományos Közleményei. Budapest, MTA Földrajztudományi kutatóintézet, CD-ROM.

KovÁcs, J. and KovÁcsné SzéKely, I. 2006a. A minta értelmezési problémái: elmélet és gyakorlat (Problems in interpreting the sample: theory and practice.). Földtani Közlöny 136. 139-146.

KovÁcs, J. and KovÁcsné SzéKely, I. 2006b. A földtani adatok adatelemzésének nehézségei (Difficulties in data geologycal analysis). In Karsztfejlödés XI. Konferencia. Ed. Veress, M., Szombathely, Berzsenyi Dániel Főiskola Természetföldrajzi Tanszék, 25-35.

Kovács, J., Hatvani, I.G., Korponai, J. and Kovácsné SzéKely, I. 2010. Morlet wavelet and autocorrelation analysis of long-term data series of the Kis-Balaton water protection system (KBWPS). Ecological Engineering 36. 1469-1477.

Kovács, J., Kiszely-Peres, B., Szalai, J. and Kovácsné Székely, I. 2011a. Periodicity in shallow groundwater level fluctuation time series on the Trans-Tisza Region, Hungary. Acta Geogarphica Geologica et Meteorologica Debrecina 4-5. 65-70. 
Kovács, J., Hatvani, I.G., Kovácsné SzéKely, I., Jakusch, P., Tanos, P. and Korponai, J. 2011 b. Key question of sampling frequency estimation during system calibration, on the example of the Kis-Balaton Water Protection System's data series, Georgicon for Agriculture. A Multidisciplinary Journal in Agricultural Sciences 14. (1): 53-68.

Kovács, J., Korponai, J., Kovácsné, Sz.I. and Hatvani, I.G. 2012. Introducing sampling frequency estimation using variograms in water research with the example of nutrient loads in the Kis-Balaton Water Protection System (W Hungary). Ecological Engineering 42. 237-243.

Kovács, J., Reskóné Nagy, M. and Kovácsné SzÉKely, I. 2005. Mintavételezés gyakoriságának vizsgálata tér-statisztikai függvénnyel a Velencei-tó példáján (Estimation of sampling frequency in Lake Velencei by spatial statistics). Hidrológiai Közlöny 85. (6): 68-71.

Kovács, J., Szabó, P. and SzAlai, J. 2004. Talajvízállás adatok idősoros vizsgálatai a DunaTisza közén (Time series analysis of shallow groundwater level In the Danube-Tisza Interfluve). Vízügyi Közlemények 86. (3-4): 607-624.

Kovács-SzÉKely, I. and SzAlaI, J. 2009. The impact of climate change on production conditions of Hungarian agriculture, especially on shallow groundwater supply. In Proceedings of Budapest Business School. Eds: Majoros, P. and Zimler, T., Budapest, Budapesti Gazdasági Főiskola, 79-96.

LADÁNYI, Zs., DeÁK, J.Á. and RAKONCZAI, J. 2010. The effect of aridification on dry and wet habitats of Illancs microregion, SW Great Hungarian Plain, Hungary. AGD Landscape $\mathcal{E}$ Environment 4. (1): 11-22.

Ladányi, Zs., Rakonczai, J., Kovács, F., Geiger, J. and DeÁk, J.Á. 2009. The effect of recent climatic change on the Great Hungarian Plain. Cereal Research Communications 37. (4): 477-480.

Liebe, P. 1994. A rétegvízkészletekés a nyomásszintek változása a Duna-Tisza közi hátságon és azok kihatása a talajoizszintekre (The alteration of the aquiferic water supplies and the pressure levels and their impact on the groundwater level in the Danube-Tisza Interfluve). A Nagyalföld Alapítvány Kötetei 3. Békéscsaba, Nagyalföld Alapítvány, 25-30.

LóкI, J. 1999. A tiszai Alföld (The area beyond the Tisza). In Pannon Encyclopaeia Magyarország földje. Ed. Karátson, D., Budapest, Kertek 2000 Publishing House, 300-301.

MáDLnÉ SzôNYI, J. and TóTH, J. 2007. „A Duna-Tisza köze vízföldtani típusszelvény” és a szikesedés összefüggései (The relationship between the hydrogeologic segment of the Danube-Tisza Interfluve and the aridification). Földrajzi Közlemények 131. (55.) (4): 343-360.

MÁdlné SzőNyi, J., Simon, Sz., TóTH, J. and PogÁcsás, Gy. 2005. Felszíni és felszín alatti vizek kapcsolata a Duna-Tisza közi Kelemen-szék és Kolon-tó esetében (The relationship between the surface water and the groundwater int he case of the Kelemen-szék and Kolon Lake in the Danube-Tisza Interfluve). Általános Földtani Szemle 30. 93-110.

Major, P. 1993. A Nagyalföld talajvízháztartása (The groundwater resources of the Great Hungarian Plain). Hidrológiai Közlöny 1. 40-44.

Major, P. 1994. Talajvizszint-süllyedések a Duna-Tisza közén (The depletion of the groundwater level in the Danube-Tisza Interfluve). A Nagyalföld Alapítvány Kötetei 3. Békéscsaba, Nagyalföld Alapítvány, 17-24.

Major, P. and NePPEL, F. 1988. A Duna-Tisza közi talajvízszint süllyedések (Groundwater level depletions in the Danube-Tisza Interfluve). Vízügyi Közlemények 70. (4): 605-626.

Matheron, G. 1965. Les Variables Regionaliées et leur Estimation (Regional variables and their distribution). Masson et Cie. Paris, 305 p.

Mezősı, G. 2011a. Az Alföld természeti képének kialakulása (The development of the landscape of the Great Hungarian Plain). In Környezeti változások és az Alföld. Ed. RAKonczAI, J. A Nagyalföld Alapítvány Kötetei 7. Békéscsaba, Nagyalföld Alapítvány, 15-24. 
Mezôsı, G. 2011b. Magyarország természeti földrajza (The physical geography of Hungary). Budapest, Akadémiai Kiadó, 393 p.

Molnár, S. and Füst, A. 2002. Környezetinformatikai modellek I. (Models in enviromental informatics I.). Gödöllö, Szent István Egyetem Kiadó, 103 p.

Molnár, S., Füst, A., Szidarovszky, F. and Molnár, M. 2010. Környezetinformatikai modellek. (Models in enviromental informatics). Gödöllő, Szent István Egyetem Kiadó, 191 p.

PÁLfAI, I. 1994. A Duna-Tisza közi hátság vízgazdálkodási problémái (The water management problems of the Danube-Tisza Interfluve). In A Duna-Tisza közi hátság vízgazdálkodási problémái. A Nagyalföld Alapítvány kötetei 3. Ed. PÁLfaI, I., Békéscsaba, Nagyalföld Alapítvány, 111-126.

PÁLfAI, I. 1996. A talajnedvesség és a talajvízállás változásai az Alföldön (The alterations in soil moisture and groundwater level in the Great Hungarian Plain). Vizügyi Közlemények 2. 207-218.

RakonczaI, J. 2011. Effects and consequences of global climate change in the Carpathian Basin. In Climate Change - Geophysical Foundations and Ecological Effects. Eds. Blanco, J. and Kheradmand, H., Rijeka, InTech, 297-322.

RAKONCZAI, J. and BóDis, K. 2002. A környezeti változások következményei az Alföld felszín alatti vízkészleteiben (The effecs of environmental changes on the groundwater supplies of the Great Hungarian Plain). In Jakucs László, a tudós, az ismeretterjesztő és a múvész. Eds. Mészáros, R., Schweitzer, F. and Tóth, J., Pécs, Pécsi Tudományegyetem - MTA Földrajztudományi Kutatóintézet, 227-238.

RÉTHÁTI, L. 1974. Talajvíz-idősorok homogenitás vizsgálata (The homogeneity analysis of the groundwater time series). Hidrológiai Közlöny 54. (1): 1-48.

RónAI, A. 1985. Az Alföld negyedidőszaki földtana (The Quaternary geology of the Great Hungarian Plain). Geologica Hungarica, Series Geologica 21. 140-142.

Shannon, C.E. 1949. Communication in the presence of noise. Proceedings of the IRE, 37. $10-21$.

Szabó, Gy. 1959. Pest belterületének hidrogeológiai viszonyairól (About the hydrogeologic situation of Pest). Hidrológiai Közlöny 59. (6): 416-424.

Szabó, Gy. 1960. A talajvízszint változása Pest belterületén (The changes in the groundwater level of Pest). Hidrológia Közlöny 60. (2): 106-115.

SzAlAi, J. 1996. A talajvízszintek változása a Duna-Tisza közén a későőszi-téli időszakban. (Changes in shallow groundwater level in the Danube-Tisza Interfluve during the late autumnwinter period). Budapest, VITUKI Rt. 12 p.

Szalai, J. and Nagy, Gy. 2006. Az utóbbi évtized idôjárási eseményeinek hatása a talajuízszintek alakulására a Duna-Tisza közén (The effects of the weather events of the last decade on the shallow groundwater level in the Danube-Tisza Interfluve). Magyar Hidrogeológiai Társulat XXIV. Országos Vándorgyülése Konferencia, Pécs, Magyar Hidrológiai Társaság, 729-745.

Szalai, J., Kovács, J. and Kovácsné Székely, I. 2011. A Duna-Tisza köze csapadék és talajvízszint-adatainak vizsgálata klaszteranalízissel (Clustering the precipitation and shallow groundwater level data series of the Danube-Tisza Interfluve). In Környezeti változások és az Alföld. A Nagyalföld Alapítvány Kötetei 7. Ed. RAKONCZAI, J., Békéscsaba, Nagyalföld Alapítvány, 111-118.

Szalai, J., Kovács, J., Kovácsné SzéKely, I., LÁzÁr, M. and Molnár, M. 2008. A talajvízszint tér- és időbeli alakulása a Duna-Tisza közén a XX. század közepétől napjainkig, kilátások (Changes in shallow groundwater level in the Danube-Tisza Interfluve from the mid $20^{\text {th }}$ century until today, expectations). In MHT XXVI. Országos Vándorgyúlés, 
Miskolc, 2008.07.2-4., Paper 26. Ed. SzLávik, L., Miskolc, Magyar Hidrológiai Társaság. CD-ROM

SzodfridT, I. 1993. Az erdő és a talajvizek kapcsolata a Duna-Tisza közi hátságon (The relationship between shallow groundwater and forests in the Danube-Tisza Interfluve). Hidrológia Közlöny 1. 44-45.

UвELL, K. 1953. Talajvíztározódás csapadékvíz hatására (The storage of shallow groundwater due to precipitation). Vízügyi Közlemények 35. (2): 448-469.

UjHÁzy, N. and Bıró, M. 2013. A vizes élőhelyek változásai Szabadszállás határában (The alterations in wetlands near Szabadszállás ). Tájökológiai Lapok 11. (2): 291-310.

Wackernagel, H. 2003. Multivariate Geostatistics. Berlin, Springer Verlag, 381 p.

Webster, R. and Oliver, M.A. 2007. Geostatistics for Environmental Scientists. $2^{\text {nd }}$ ed. Chichester, John Wiley and Sons, 330 p. 